\title{
ПОИСК БИОЛОГИЧЕСКИ АКТИВНЫХ ВЕЩЕСТВ НА ОСНОВЕ ПОЛИФУНКЦИОНАЛЬНЫХ ПРОИЗВОДНЫХ МОНО- И СЕСКВИТЕРПЕНОИДОВ
}

\author{
С.А. Рубцова, Д.В. Судариков, Ю.В. Гырдымова, Н.О. Ильченко,
}

\author{
А.В. Кучин \\ Институт химии ФИЦ Коми НЦ УрО РАН, \\ 167000, Россия, г. Сыктывкар, ул. Первомайская, 48.
}

DOI: 10.19163/MedChemRussia2021-2021-137_E-mail: rubtsova-sa@chemi.komisc.ru

Поиск новых лекарственных противомикробных средств остается приоритетной задачей медицинской и органической химии в силу возникающей резистентности микроорганизмов и вирусов к существующим лекарственным препаратам. К числу природных соединений, перспективных в качестве основы для создания новых противомикробных и противовирусных субстанций, относятся соединения терпенового ряда.

В докладе обсуждаются аспекты синтеза, стереохимии и биологической активности новых синтезированных S-, O-, N-, F-содержащих производных моно- и сесквитерпеноидов и их конъюгатов с известными фармакофорами. Введение в молекулу биологически активного вещества компактного липофильного моно- и сесквитерпенового фрагмента влияет на мембранный транспорт и связывание с биологической мембраной, что позволяет ожидать усиление биологической активности новых соединений, а также мультитаргетного эффекта.

Установлено, что некоторые сульфен-и сульфинимины, а также фторсодержащие сульфинамиды на основе 4-карантиола проявляют антибактериальную и противогрибковую активность в отношении Acinetobacter baumannii и Candida albicans [1]. Тиолсульфонаты пинановой структуры показали активность в отношении Candida albicans, Staphylococcus aureus и Cryptococcus neoformans [2].

S-Содержащие производные сесквитерпеновых тиолов, их виниловые тиоэфиры, симметричные и несимметричные дисульфиды, содержащие 4,5-эпоксикариофилланил- или 5-гидроксикариофилленовые фрагменты, бис-сульфиды активны в отношении вируса гриппа типа A(H1N1) [3].

Работа выполнена при частичной финансовой поддержке РНФ (грант

№ 21-13-00245) с использованием оборудования ЦКП «Химия» Института ХимиИ ФИЦ Коми НЦ УРО РАН.

\section{Литература}

[1] D.V. Sudarikov, Yu.V. Krymskaya, N.O. Il'chenko, P.A. Slepukhin, S.A. Rubtsova, A.V. Kutchin, Russ. Chem. Bull. 2018, 67, 731-742.

[2] O.N. Grebyonkina, O.M. Lezina, E.S. Izmest'ev, D.V. Sudarikov, S.V. Pestova, S.A. Rubtsova, A.V. Kutchin, Russ. J. Org. Chem. 2017, 53, 860-868.

[3] Y.V. Gyrdymova, E.O. Sinegubova, A.S. Muryleva, V.V. Zarubaev, S.A. Rubtsova, Chem Nat Compd. 2019, 55, 1179-1181. 